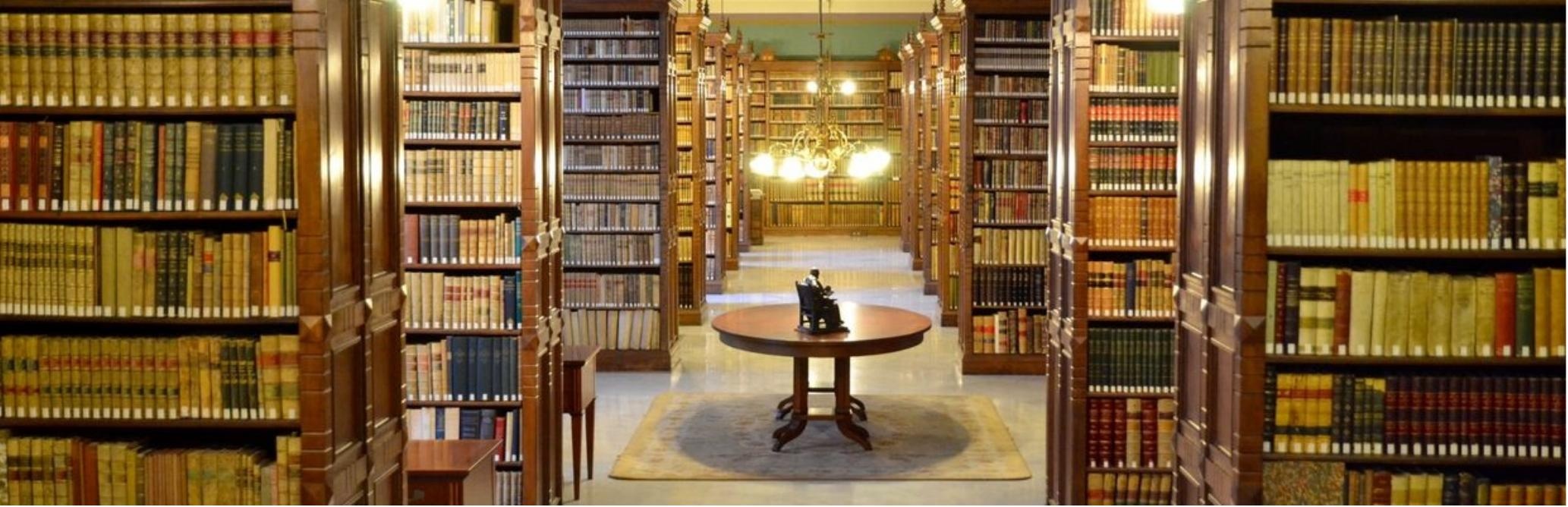

\title{
Editorial Volume 7, Issue 1
}

$\begin{aligned} \text { Authors: } & \text { María Fernanda Sandoval } \\ \text { Submitted: } & \text { 1. March } 2020 \\ \text { Published: } & \text { 1. March } 2020 \\ \text { Volume: } & 7 \\ \text { Issue: } & 1 \\ \text { Affiliation: } & \text { IASHA e.V., Freiburg, Germany } \\ \text { Languages: } & \text { English } \\ \text { Keywords: } & \text { Editorial, Josha Journal, } 2020 \text { January - February } \\ \text { Categories: } & \text { News and Views } \\ \text { DOI: } & 10.17160 / \text { josha.7.1.641 }\end{aligned}$

Abstract:

Dear JOSHA readers, once again we find ourselves saying goodbye and closing another issue. This time it is the first one for the year 2020, which is full of important changes for our non-profit journal. Among other things, we must inform you all that our editorials will be published every two months, that is, from 2020 all our issues will be published bimonthly, always on the 30th of every second month. We also like to remind that you can upload a video link of YouTube to your article!

\section{JOSHA Jouna ofsemeree Humanities and Arts}




\section{JOSHA - Journal of Science Humanities and Arts Editorial Volume 7 Issue 1}

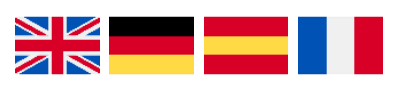

Dear JOSHA readers, once again we find ourselves saying goodbye and closing another issue. This time it is the first one for the year 2020, which is full of important changes for our non-profit journal. Among other things, we must inform you all that our editorials will be published every two months, that is, from 2020 all our issues will be published bimonthly, always on the 30th of every second month. We also like to remind that you can upload a video link of YouTube to your article!

\section{Watch Video}

In another framework of ideas, you can immediately submit your work by mail to admin@joshaarchive.org to participate in our Demetrios Prizes 2020. More information about this project will be published as usual in our category News \&Views. However, we can tell you that this year our Demetrios Prize will have some changes. Keep connected with our social media accounts (Facebook \& Instagram) to see and get more information about this wonderful idea to promote and support the talent of young students all around the world.

In the same way, we were receiving around 100 articles that confirm a total of more than 350 articles since 2014 with more than 600,000 visits and almost 500,000 downloads. Concerning our first issue of this year, a total of 6 articles were published between January and February. All of them belonging to the areas of medicine, architecture

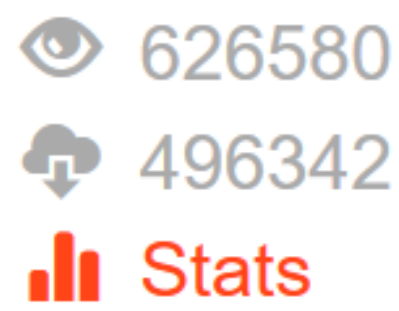
and design, visual arts, and politics.

We are happy to carry on a successful way with all your support and hope to have a wonderful Sommer overflowing with endless interesting articles from all over the world. Together, we have achieved so much exile in such a short time. Therefore, we thank you and promise to continue to work to connect more 
authors around the world and continue to share important knowledge, because the knowledge that is not communicated is wasted knowledge!

The Editorial Board and everybody in JOSHA would like to thank our readers and authors for supporting this project.

We wish all our readers a joyful reading experience at JOSHA!

Table of content: http://josha-journal.org/en/issues

Maria Sandoval, Editorial Volume 7, Issue 1

Silvia Juliana Barajas Rueda, Carlos Hernan Becerra, Correlation between ultrasound diagnosis of chorionicity with postpartum placental histopathology and the risk of adverse perinatal outcomes in monochorionic twin pregnancies

Astrid Paola A. Cuervo, Franco Garcia, Rocio Guarin, THE EFFECT OF CERVICAL CANCER SURGICAL MANAGEMENT ON SEXUAL FUNCTION IN A NORTHEASTERN COLOMBIAN HOSPITAL

Juan Carlos Otero Pinto, Sergio Andres Calvo Castro et al., Evaluation of the determinants of magnesemia in patients with preeclampsia with severe features treated according to 2013 task force Figo protocol. By Dr. Katherine Bahamon Florez.

Harald A. Mieg, A Two-Path Process Model of Invention: Conclusions from six years of research with independent inventors

Bujar Q. Bajçinovci, FridaysForFuture: Environmental Sustainable Architecture Collection of Research Papers

Mike Omilusi, Freedom of Expression as Threat to National Security: Self-Determination, Radio Biafra and the Political Space in Nigeria

Hans-Liudger Dienel, Christoph Henseler, Landkarten des Ungewissen als Werkzeug in der angewandten Zukunftsforschung

Maria Fernanda Sandoval on behalf of the JOSHA Team 